\title{
Psychometric parameters of the subscale of hostility from the Symptom Checklist 90 (SCL-90)
}

\author{
Jaqueline Gomes Cavalcanti ${ }^{1}$ \\ Giovanna Barroca de Moura ${ }^{2}$ \\ Carlos Eduardo Pimentel \\ ${ }^{1}$ Instituto de Educação Superior da Paraíba (IESP) \\ ${ }^{2}$ Universidade Estadual Vale do Acaraú, Sobral, CE \\ ${ }^{3}$ Universidade Federal da Paraíba, João Pessoa, PB
}

\begin{abstract}
The present study aimed to know the psychometric parameters of the SCL-90 hostility scale. For this, two studies were traced; In Study 1, 209 students, mean age 16 years $(S D=1.29)$, who responded to the Scale of Hostility and a sociodemographic questionnaire. The exploratory factorial analysis indicated a unidimensional structure, whose Cronbach's alpha was.71. In Study 2 , we sought to find additional evidence of validity and reliability counting with 212 students with a mean age of 16 years (SD = 1.19). The confirmatory factorial analysis tested the unifactorial structure and pointed to good adjustment indexes; good internal consistency and composite reliability were also observed. In general, the Scale of Hostility provided evidence of satisfactory validity and reliability.

Keywords: hostility; validity; reliability; psychometry
\end{abstract}

Parâmetros Psicométricos da Subescala de Hostilidade da Symptom Checklist 90 (SCL-90)

\begin{abstract}
Resumo
O presente estudo objetivou conhecer os parâmetros psicométricos da subescala de hostilidade da SCL-90. Para isso, traçou-se dois estudos; no Estudo 1 buscou-se conhecer evidências de validade e precisão da subescala de hostilidade. Contou-se com 209 estudantes, com média de 16 anos de idade $(D P=1,29)$, os quais responderam a Subescala de Hostilidade e um questionário sociodemográfico. A análise fatorial exploratória indicou uma estrutura unifatorial, cujo alfa de Cronbach foi 0,71 . No Estudo 2 buscou-se encontrar evidências adicionais de validade e precisão contando-se com 212 alunos com média de idade de 16 anos $(D P=1,19)$. A análise fatorial confirmatória testou a estrutura unifatorial e apontou para bons índices de ajuste; também se verificaram bons índices de consistência interna e confiabilidade composta. De modo geral, a Subescala de Hostilidade apresentou evidências de validade e precisão satisfatórias.

Palavras-chave: hostilidade, validade, precisão, psicometria
\end{abstract}

Parámetros Psicométricos de la Subescala de Hostilidad de la Symptom Checklist 90 (SCL-90)

\section{Resumen}

El presente estudio tuvo como objetivo conocer los parámetros psicométricos de la Subescala de Hostilidad de la SCL-90. Se realizaron dos estudios; en el primer estudio se trataron de encontrar evidencias de validez y precisión de la subescala de hostilidad; participaron 209 estudiantes, con promedio de edad de 16 años (DP = 1,29), los cuales respondieron la Subescala de Hostilidad y un cuestionario sociodemográfico. El análisis factorial exploratorio indicó una estructura unifactorial, cuyo alfa de Cronbach fue de 0,71 . En el segundo estudio, se trataron de encontrar evidencias adicionales de validez y precisión, contando con 212 alumnos con promedio de edad de 16 años (DP = 1,19). El análisis factorial confirmatorio probó la estructura unifactorial y señaló buenos índices de ajuste; también se verificaron buenos índices de consistencia interna y confiabilidad compuesta. En general, la Subescala de Hostilidad presentó evidencias de validez y precisión satisfactorias.

Palabras clave: hostilidad; validez; precisión; psicometría

\section{Introduction}

Hostility has been pointed out as an explanatory variable of aggressive, antisocial and deliquescent behaviors (Ansell, et al., 2015; Birkley \& Eckhardt, 2015; Helfritz-Sinville \& Stanford, 2014; Cavalcanti \& Pimentel, 2016); as well as a risk factor for the health and the psychological well-being of people (Assari, 2017; Perk et al., 2012; Rafanelli et al., 2016; Fischer et al., 2015; Stoney, 2013), being, therefore, a construct of considerable interest in psychology. About it, some of the correlates of hostility found in the literature are: depression (Fischer et al., 2015); cardiovascular disease (Perk et al., 2012); Internet addiction in adolescents (Ko et al., 2014), cigarette (Bernstein et al., 2014) and drugs use (Ansell et al., 2015), aggressive behavior (Cavalcanti $\&$ Pimentel, 2016) and partner violence (Birkley \& Eckhardt, 2015).

Although hostility is a widely studied subject, its definition is still quite ambiguous and often confusing, 
being commonly associated with concepts such as aggression and anger, or sometimes treated as synonyms. However, it should be stressed that these are conceptually distinct terms, for instance, aggression (aggressione) means any behavior directed to another individual with the intention of causing harm (Bushman, 2016). In turn, anger refers to emotional state encompassing feelings ranging from mild annoyance to intense fury and anger, accompanied by autonomic nervous system stimulation (Spielberger \& Biaggio, 1992). And as far as hostility is concerned, it is constituted as a belief, expectation and negative attitudes toward persons and things (Smith1992; Siegman \& Smith, 2013).

Despite this, Barefoot (1992) emphasizes that the aggression relates to a behavioral component; anger signals an affective-emotional component and in turn, the hostility comes to a cognitive component. In a different way, Matthews, Jamison And Cottington, (1985) highlighted the hostility as a multidimensional construct composed of cognitive, affective and behavioral components The cognitive component is defined as negative beliefs and attitudes in relation to others, including cynicism and mistrust. The affective component typically labeled as anger, refers to an unpleasant emotion that varies from the anger and irritation can be assessed in relation to the frequency, intensity and target. On the other hand, the behavioral component results from an attitudinal and affective component and is an action that aims to harm others, verbally or physically.

The definition to which present study was anchored was Derogatis et al. (1976), which understands hostility as a concept encompassing cognitive, emotional and behavioral aspects. For these authors, hostility concerns thoughts, feelings or actions, characteristics of the state of negative anger, reflecting traits such as aggression, irritability, anger and resentment.

Regarding evaluation of hostility, some instruments available in the literature are: (1) Scale of Hostility of Cook-Medley (Ho, Cook \& Medley, 1954); (2) the Inventory of Hostility-Guilt (Buss \& Durke, 1957); (3) Questionnaire of Aggression (Buss \& Perry, 1992); and (4) Scale of Assessment of Symptoms (SCL-90-R-90, Derogatis, 1976).

Derived from the Minnesota Multiphase Personality Inventory (MMPI), the Scale of the Hostility of Cook-Medley (Cook \& Medley, 1954) has 50 items and evaluates such factors as: cynicism, hostile affection, aggressive response, hostile assignment, social avoidance and other (Barefoot et al.,1991). Unlike Ho, which consisted in items from the MMPI, the Inventory of Hostility-Guilty (Buss \& Durke, 1957) sought to group items into sub scales representing various aspects of hostility, such as: verbal and indirect hostility. This scale has 75 items in a format that is true or false and brings the total of 8 factors: seeking to highlight the indirect violence, hostility, irritability, negativism, resentment, distrust, hostility verbal and guilt. This measure although widely used, was not fully supported by factor analytic studies and has also been criticized regarding their used practice and theoretical clarity. In addition, it received criticism regarding the response scale employed, which was the true-false, that are known only results and what motivated the construction of the Hostility-Guilt Inventory of Buss and Durkee (Fernandez \& Gregory, 2014).

In a review of the Hostility-Guilt Inventory of Buss and Durkee (1957), Buss and Perry (1992) developed the Aggression Questionnaire comprising 29 items that assess four factors: physical aggression, verbal aggression, anger and hostility. These items are answered on a scale of five points, Likert scale, ranging from $1=$ totally disagree to $5=$ totally agree. Its adaptation to Brazil was presented by Gouveia, Peregrino, Branco e Gonçalves (2008). A satisfactory internal consistency was found for the hostility factor, composed of 8 items $(\alpha=0,77)$.

Finally, there is an emphasis in the Symptom Assessment Scale-90-R (SCL-90-R), which formulation was made by Leonard R. Derogatis departing from previous studies with a Hopkings Symptom Cheklist HSCL, published on 1975 (Laloni, 2001). Composed of 90 self-assessment items ranging from 0 to 4 , this scale aims to measure psychiatric and psychological symptoms of psychiatric and non-psychiatric patients, evaluating 9 symptomatic dimensions: somatization, obsessiveness, compulsiveness, interpersonal sensitivity, depression, anxiety, hostility, phobic anxiety, paranoid ideas and psychoticism. For the hostility factor, the original study pointed to an alpha of 0,84 (Derogatis, 1976), and considering its adaptation to the Brazilian context, made by Laloni (2001), presented an alpha of 0,79

Although above instruments have limitations, such as: great number of items Cook \& Medley, 1954; Buss and Durkee, 1957) and lack of applicability to the clinical context (Buss and Perry, 1992; Buss and Durkee, 1957). For these reasons, the SCL-90 hostility subscale was chosen, considering that this measure is one of the instruments most used in practice and in the research 
focused on the evaluation of mental health, relevant both for use with clinical and non-clinical samples (Prunas et al., 2012; Prinz et al., 2013; Sereda \& Dembitskyi, 2016; Carrozzino et al., 2016; Tan et al., 2015). Furthermore, its applicability was considered acceptable in different countries, such as, for example, Africa, Denmark, Norway, Italy, Thailand, Ukraine and China (Carrozzino et al, 2016; Chapman \& Vines, 2012; Tan et al., 2015; Prunas et al., 2012; Sereda \& Dembitskyi, 2016; Wongpakaran et al., 2011). In addition, although the SCL-90 hostility subscale had its parameters tested for the Brazilian context, it was analyzed together with the 90 items of the SCL-90, having been performed for more than a decade only for clinical sample (Laloni, 2001).

In this sense, this study aimed to know the psychometric parameters of the Hostility Subscale of SCL 90 in a non-clinical sample. Therefore, a cross-validation was performed, through two studies: the first one that used the exploratory factorial analysis and the second that started from the confirmatory factorial analysis.

\section{Study 1: Hostility Subscale Exploratory Factor}

\section{Structure}

It was a cross-sectional psychometric study, whose objective was to know the evidences of its factorial validity and internal consistency, through exploratory analyzes.

\section{Method}

\section{Participants}

For this research, it was used a sample of 215 students from public and private schools in the city of Guarabira (PB), with ages ranging from 13 to 23 years $(M=16,11 ; D P=1,29)$, the majority is female $(53,7 \%)$, single people $(85,1 \%)$, from the second year of high school $(42,8 \%)$ and middle class(50,2\%).

\section{Instruments}

The Hostility Subscale (HS), certified for Brazil by Laloni (2001), is included in the Symptom Cheklist - 90 - SCL - 90 (Derogatis, 1975) and aims to select people with or without psychiatric intervention. As for the Hostility Subscale it is composed of 6 items, whose scale of response varies from $1=$ Never to $4=$ Always. High scores point to a high level of hostility; in contrast, low score indicates a lower level of hostility. Regarding the psychometric aspects, the reliability of this subscale in the original study was 0.84 ; and the temporal stability was 0.78 (Derogatis et al., 1976). It was observed, in its Brazilian version, a good internal consistency index of
0.79 (mean correlation of 0.40 ) and correlation coefficient of test-retest accuracy in the 7 to 15 days period was 0.79 (Laloni, 2001).

A sociodemographic questionnaire was also used to trace the sociodemographic profile of the participants, whose questions were: gender, age, grade, social class, educational network and marital status.

\section{Procedure}

Before beginning the survey, permission was obtained from school principals; after the consent, the data collections were scheduled, according to the availability of the teachers and the class schedule. For data collection, the objectives of the study were presented as well as the voluntary nature of the research. Those who expressed an interest in participating in the research were asked for the prior authorization of the parents/ guardians, by signing the Termo de Consentimento Livre e Esclarecido, according to the requirement of the Código de Ética for human research (Resolution 466/12). The students were also asked to sign the agreement. As for the response instructions, the researchers instructed the students to answer to the set of instruments individually, leaving them free to drop out at any time. Finally, thanks were sent to students, teachers and school principals. The average time for students to respond was approximately 5 minutes.

It is important to emphasize that the project that resulted in this article was approved by the Ethics Committee of Universidade Federal da Paraíba (CAAE: 27743214.1.0000.5188).

\section{Data analysis}

Descriptive analysis, inferential and main component analysis were performed using the Hull-Comparative Fit Index. This factorial retention method when compared to the Kaiser-Guttman (eigenvalue> 1), Cattell test (scree plot), parallel analyzes and partial minimum average method, obtained better results (Lorenzo-Seva et al., 2011). To carry out the descriptive analyzes, it was used the software IBM-SPSS (version 21); and for the other analyzes the software Factor - version 10.0 (Lorenzo-Seva \& Ferrando, 2013) was preferred, using the polychoric correlation matrix, the ULS extraction method and promin rotation.

\section{Results}

Initially, to study the validity based on the internal structure of the Hostility Subscale, an exploratory 
factorial analysis was performed from the polyclonal correlation matrix, which was adequate $[\mathrm{KMO}=$ 0.75 and Bartlett's Sphericity Test, $\left[\chi^{2}(15)=193.2, \mathrm{p}\right.$ $<0.001)]$. In order to determine the number of factors, the Hull method was chosen (Lorenzo-Seva et al., 2011), adopting the Unweighted Least Squares measurer (ULS) and the promin rotation, that detected to an unifactorial solution (Table 1), with eigenvalue equal to 2.42 , explaining $40.33 \%$ of the total variance.

As for the values of factorial loads, as shown in Table 2, they were higher than 0.40 and statistically different from zero $(p<0.001)$ for all items. This version of the subscale had an internal consistency (Cronbach's Alpha) of 0.71 .

\section{Partial discussion}

In general, the present study met its objective that was to know evidences of its factorial validity and internal consistency. An unifactorial structure was indicated, using the method of Hull-Comparative Fit Index, confirming the original study proposal (Derogatis., 1976). Factorial loads were higher than those indicated by Hair et al. (2009) delimiting 0.30; so that in the present study in general it was above 0.50 ; presenting only item 3 with a load of 0.42 . In addition, there was a satisfactory internal consistency as suggested by the literature (Oviedo \& Campo-Arias, 2005; Pasquali, 2010). Despite these results, it is essential to highlight that these are exploratory analyzes, and it is not known if the scores of the HS are affected by social desirability, which is common in terms of self-report measures For these reasons the Study 2 was used, as described below.

Study 2: Hostility Subscale Confirmation Analysis

This study was based on a cross-sectional psychometric study and was aimed at gathering additional evidence of factorial validity and reliability of HS in a new sample, based on confirmatory factor analysis (CFA).

Table 1.

Hull method for number of factors selection

\begin{tabular}{cccc}
\hline \multicolumn{2}{c}{ Goodness-of-fit index: Method for drawing dimensions: } & \multicolumn{2}{c}{ CFI (Comparative Fit Index). ULS } \\
\hline number of factors & Values of Goodness-of-fit & g.l & Values of the Scree test \\
\hline 0 & 0.00 & 6 & 0.000 \\
1 & 0.97 & 12 & $22.167^{*}$ \\
2 & 1.00 & 17 & 0.000 \\
\hline
\end{tabular}

Note: *Directions about the number of common factors 1

Table 2.

Hostility Subscale Factorial Structure

\begin{tabular}{lcc}
\hline Items & Factor & \\
\hline & 1 & $\mathrm{~h}^{2}$ \\
\hline 1. Sente-se facilmente aborrecido ou irritado? & 0.56 & 0.31 \\
2. Tem acessos de raiva que não pode controlar? & 0.56 & 0.31 \\
3. Se instiga a bater, ferir ou prejudicar alguém? & 0.42 & 0.18 \\
4. Se instiga a quebrar ou destruir coisas? & 0.59 & 0.35 \\
5. Entra em discussões frequentes? & 0.57 & 0.32 \\
6 Grita ou atira coisas? & 0.50 & 0.25 \\
Eigenvalue & 2.42 & \\
Explained Variance & $40,33 \%$ & \\
Alfa de Cronbach & 0.71 & \\
\hline
\end{tabular}




\section{Method}

\section{Participants}

For this research, it was used a sample of 212 students from public and private schools in the city of Guarabira, with ages ranging from 13 to 21 years $(M=15,97 ; D P=1,19)$, the majority is female $(53,3 \%)$, single people $(85,8 \%)$, from the second year of high school (42,5\%) and middle class (52,8\%).

\section{Instruments}

The same instruments of Study 1 were used, plus Stöber's Social Desirability Scale (SDS, 2001). The SDS, an unifactorial measurement, has 16 items which are answered dichotomously, ("true" or "false"). Some examples of items are: "1. 1. I sometimes litter. T () F ( )" or " 10 . When I have made a promise, I keep it--no ifs, ands or buts. T () F ()". This measure in its original study presented good psychometric parameters, with a Cronbach's alpha of 0.72 and a test-retest correlation of 0.82 in four weeks.

\section{Procedure}

The procedures were the same as in Study 1, however, there was a longer application time, since a new instrument was added. The average time was about 10 minutes.

\section{Data analysis}

The confirmatory factorial analysis (CFA) was performed from R software and Lavaan package, however, the AMOS software was used for configuring the figure. It was used in this analysis the substantial estimation method called WLSMV (Weighted Least Squares Mean and Variability-Adjusted), which is indicated for use in non-parametric data (Brown, 2006).

To evaluate the adequacy of the model, the following adjustment indicators were considered: $\chi^{2} / g l$ (acceptable $<5$ ), Comparative Fit Index (CFI; acceptable $>0,90, \operatorname{good} \geq 0,95$ ), Goodness-of-Fit Index (GFI, acceptable > 0,90), Tucker Lewis Index (TLI; acceptable $>0,90$, good $\geq 0,95$ ), Root Mean Square Error Approximation (RMSEA; acceptable< 0,08) (Byrne, 2010; Hair et al., 2009).

\section{Results}

The objective was to test the one factor model found in Study 1, for this, we proceeded with a CFA assuming that the set of items were saturated in a single factor. The results pointed to good adjustment indicators: $\chi^{2}(9)=4,713, \mathrm{p}<0,001 \chi^{2} /$ g.l. $=0,52$; $[\mathrm{CFI}=1,00 ; \mathrm{GFI}=0,99 ; \mathrm{TLI}=1,04 ; \mathrm{RMSEA}=0,00$, p-close $=0,59(\operatorname{IC~} 90 \%=0,04 ; 0,09)]$.

In Figure 1, the final confirmatory factorial structure can be seen. All HS items presented statistically different saturations (factorial weights, $\lambda$ ) from zero $(p<0.001)$.

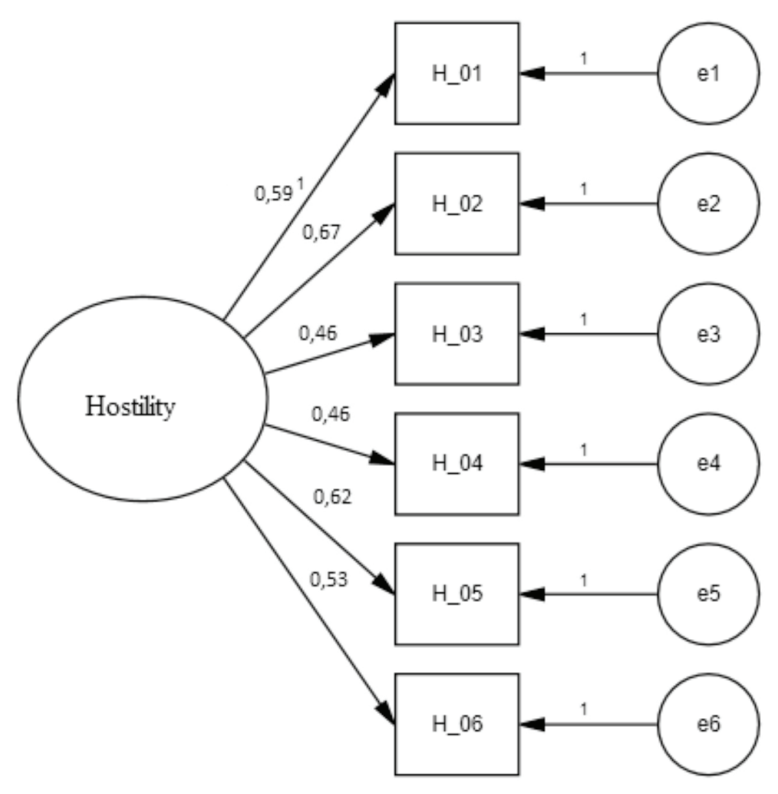

Figure 1. One-Factor

There was also a positive correlation between the HS and the SDS $(r=0.37, \mathrm{p}<0.01)$, which indicates that high scores on hostility are accompanied by high scores on social desirability, usual in self-report measures. Finally, the Cronbach's alpha was calculated for the set of HS items, presenting a good index $(\alpha=0.73)$, as well as a good composed reliability $(\mathrm{CC}=0.73)$.

\section{Partial discussion}

In short, the results confirm the unifactorial structure of the HS, bringing together 6 items that presented good indexes of adjustment, as indicated by authors of the area (Tabachnick \& Fidell, 2013). In terms of precision indexes (Cronbach's Alpha and composed reliability) were considered adequate since they met the recommendations of the literature (Oviedo \& CampoArias, 2005; Pasquali, 2010). Finally, it was possible to 
verify correlations between hostility and social desirability, suggesting that this measure should take into account the control of desirability.

\section{Final Discussion}

The present article sought to know the psychometric parameters of the HS for a Brazilian sample. The results confirmed the unifactorial structure proposed by the measure originally developed by Derogatis (1975). In this sense, it is suggested that this measure has construct validity, since the observed factors are in line with what was expected (Pacico \& Hutz, 2015). The unifactorial structure was supported by the use of the confirmatory factorial analysis in which good indexes of adjustments were verified for the parameters adopted (RMSEA, CFI, TLI, GFI), as suggested by the literature (Byrne, 2010).

The exploratory study and confirmatory study indicators showed satisfactory psychometric adequacy, with acceptable reliability indexes above 0.70 , as recommended by the theorists mentioned in the area (Nunnally, 1970; Oviedo \& Campo-Arias, 2005). ; Pasquali, 2010), as well as a satisfactory composite reliability in Study 2. These results converge with those obtained by Prunas et al. (2012); Sereda and Dembitskyi (2016); Laloni (2001) who found good index of internal consistency in their studies for the HS.

It was also sought to verify if the answer bias commonly present in self-report research, social desirability (Stöber, 2001), would be related to the HS. The results pointed to a moderate relationship between them, which suggests, in turn, future investigations able to use the measure of hostility controlling the social desirability influence.

Regarding the limitations of this research, it is worth pointing out the regionalization of the students, exclusively form the state of Paraíba, and it is relevant to know how this measure can be understood by other states. In addition, it is important to consider the fragility of the sample composed exclusively of high school students, and it is important to know the validity of this scale for other age groups. Finally, the convergent validity of the HS with other measures of hostility (eg, Ho, Cook-Medley, 1954; Buss \& Durke's Hostility-Blame Inventory, 1957) was not examined; therefore, these aspects are suggestions for future studies. Furthermore, studies that can verify evidences of discriminant and predictive validity are also recommended; and to prove their temporal stability (test-retest).
Even if such limitations are presented, it is hoped to offer a relevant contribution to the theme, by making available to the Brazilian context the adaptation of a short and specific measure to evaluate hostility, with satisfactory psychometric qualities. Its application can be useful for the researches that pursues to know impacts of hostility on antisocial behavior, health and well-being. In addition it can contribute in the evaluation of hostile profiles, as well as in the construction of interventions next to groups that score high in hostility.

\section{References}

Ansell, E. B., Laws, H. B., Roche, M. J., \& Sinha, R. (2015). Effects of marijuana use on impulsivity and hostility in daily life. Drug and Alcohol Dependence, 148, 136-142. doi: 10.1016/j.drugalcdep.2014.12.029.

Assari, S. (2017). Hostility, anger, and cardiovascular mortality among Blacks and Whites. Research in Cardiovascular Medicine, 6(1). doi: 10.5812/ cardiovascmed.34029.

Barefoot, J. C., Peterson, B. L., Dahlstrom, W. G., Siegler, I. C., Anderson, N. B., \& Williams Jr, R. B. (1991). Hostility patterns and health implications: correlates of Cook-Medley Hostility Scale scores in a national survey. Health Psychology, 10(1), 18-24. doi: 10.1037/0278-6133.10.1.18.

Barefoot, J. C. (1992). Developments in the measurement of Hostility. In H. S. Friedman (Eds.). Hostility, coping and health. (pp. 13-21). Washington: American Psychological Association.

Bernstein, M. H., Colby, S. M., Bidwell, L. C., Kahler, C. W., \& Leventhal, A. M. (2014). Hostility and cigarette use: a comparison between smokers and nonsmokers in a matched sample of adolescents. Nicotine \& Tobacco Research, 16(8), 1085-1093. doi: $10.1093 / \mathrm{ntr} / \mathrm{ntu} 033$.

Birkley, E. L., \& Eckhardt, C. I. (2015). Anger, hostility, internalizing negative emotions, and intimate partner violence perpetration: A meta-analytic review. Clinical Psychology Review, 37, 40-56. doi: 10.1016/j. cpr.2015.01.002.

Brown, T. A. (2006). Confirmatory factor analysis for applied research. New York The Guilford Press.

Bushman, B. J. (Ed.). (2016). Aggression and Violence: A Social Psychological Perspective. Psychology Press.

Psico-USF, Bragança Paulista, v. 24, n. 2, p. 373-381, abr./jun. 2019 
Buss, A. H., \& Durkee, A. (1957). An inventory for assessing different kinds of hostility. Journal of Consulting Psychology, 21(4), 343-349. doi: 10.1037/ h0046900.

Buss, A. H., \& Perry, M. (1992). The Aggression Questionnaire. Journal of Personality and Social Psychology, 63(3), 452-459.doi:10.1037/0022-3514.63.3.452.

Byrne, B. M. (2010). Structural equation modeling with Amos: Basic concepts, applications, and programmimg. New York: Routledge.

Carrozzino, D., Vassend, O., Bjørndal, F., Pignolo, C., Olsen, L. R., \& Bech, P. (2016). A clinimetric analysis of the Hopkins Symptom Checklist (SCL-90-R) in general population studies (Denmark, Norway, and Italy). Nordic journal of psychiatry, 70(5), 374379. doi: 10.3109/08039488.2016.1155235

Cavalcanti,J. G., \& Pimentel, C.E. (2016). Personality and aggression: A contribution of the General Aggression Model. Estudos de Psicologia (Campinas), 33(3), 443-451.doi: 10.1590/1982-02752016000300008

Chapman, L. K., Petrie, J., \& Vines, L. (2012). Factor structure analysis of the SCL-90-R in a community-based sample of African American women. Psychiatry Research, 199(2), 140-144. doi: 10.1016/j. psychres.2012.03.028.

Cook, W. W., \& Medley, D. M. (1954). Proposed hostility and pharisaic-virtue scales for the MMPI. Journal of Applied Psychology, 38(6), 414-418.doi: 10.1037/ h0060667.

Derogatis, L. R., Rickels, K., \& Rock, A. F. (1976). The SCL-90 and the MMPI: a step in the validation of a new self-report scale. The British Journal of Psychiatry, 128(3), 280-289. doi: 10.1192/bjp.128.3.280.

Derogatis, L. R., Yevzeroff, H., \& Wittelsberger, B. (1975). Social class, psychological disorder, and the nature of the psychopathologic indicator. Journal of Consulting and Clinical Psychology, 43(2), 183-191. doi: 10.1037/h0076514.

Fernandez, A. D. \& Gregory J. B. (2014). Measures of Anger and Hostility in Adults. In: Gregory J. B, Donald H. S., \& Gerald M. (ed), Measures of Personality and Social Psychological Constructs. Oxford: Academic Press.

Fisher, L. B., Fava, M., Doros, G. D., Alpert, J. E., Henry, M., Huz, I., \& Freeman, M. P. (2015). The role of anger/hostility in treatment-resistant depression: a secondary analysis from the ADAPT-a study. The Journal of Nervous and Mental Disease, 203(10), 762768. doi: 10.1097/NMD.0000000000000364.

Gouveia, V. V., Cruz Marques Chaves, C. M., Ramos Peregrino, R., Ortins Castello Branco, A., \& Pereira Gonçalves, M. (2008). Medindo a agressão: o Questionário de Buss-Perry. Arquivos Brasileiros de Psicologia, 60(3) 92-103. Recuperado de http:// www.redalyc.org/html/2290/229017563010/.

Hair, J. F., Jr., Black, W. C., Babin, B. J., Anderson, R. E., \& Tatham, R. L. (2006). Multivariate data analysis ( $6^{\text {th }}$ ed.). Upper Saddle River, NJ: Pearson Prentice Hall.

Helfritz-Sinville, L. E., \& Stanford, M. S. (2014). Hostile attribution bias in impulsive and premeditated aggression. Personality and Individual Differences, 56, 45-50. doi: 10.1016/j.paid.2013.08.017.

Hu, L. \& Bentler, P. (1999). Cutoff criteria for fit indices in covariance structure analysis: conventional criteria versus new alternatives. Structural Equation Modeling, 6(1), 1-55. doi: 10.1080/10705519909540118.

Ko, C. H., Liu, T. L., Wang, P. W., Chen, C. S., Yen, C. F., \& Yen, J. Y. (2014). The exacerbation of depression, hostility, and social anxiety in the course of internet addiction among adolescents: a prospective study. Comprehensive Psychiatry, 55(6), 1377-1384. doi: 10.1016/j.comppsych.2014.05.003.

Laloni, D. T. (2001). Symptom Assessment Scale-90-RSCL-90-R: Adaptation, accuracy and validity. Tese de Douturado, Pontifícia Universidade Católica de Campinas, Campinas, São Paulo, Brasil Recovered from http://tede.bibliotecadigital.puc-campinas. edu.br:8080/jspui/handle/tede/389.

Lorenzo-Seva, U., Timmerman, M. E., \& Kiers, H. A. (2011). The Hull method for selecting the number of common factors. Multivariate Behavioral Research, 46(2), 340-364.doi: 10.1080/00273171.2011.564527.

Lorenzo-Seva, U., \& Ferrando, P. J. (2013). FACTOR 9.2: A Comprehensive Program for Fitting Exploratory and Semiconfirmatory Factor Analysis and IRT Models. Applied Psychological Measurement, 37(6), 497-498. doi: 10.1177/0146621613487794

Matthews, K. A., Jamison, J. W., \& Cottington, E. M. (1985). Appendix: Assessment of Type A, anger, and hostility: A review of scales through 1982. In A. M. Ostfeld 
\& Trait Anger ABCs 895 E. D. Eaker (Eds.), Measuring psychosocial variables in epidemiologic studies of cardiovascular disease: Proceedings of a workshop (NIH publication no. 85-227

Nunnally, J. C. (1970). Introduction to Psychological Measurement. New York: McGraw-Hill Book Company.

Oviedo, H.C \& Campo-Árias, A. (2005). Aproximación al uso del coeficiente alfa de Cronbach. Revista Colombiana de Psiquiatría, 34(4), 527-580. Recovered from http://www.redalyc.org/pdf/806/80634409. pdf.

Pacico, J.C. \& Hutz, C.S. (2015). Validity. In C.S.Hutz, D.R.Bandeira \& C.M.Trentini (Orgs.), Psicometria (pp. 71-84). Porto Alegre: ArtMed.

Pasquali, L. (2010). Instrumentação psicológica: Fundamentos e práticas. Porto Alegre: ArtMed.

Perk, J., De Backer, G., Gohlke, H., Graham, I., Reiner, Ž., Verschuren, W. M., ... \& Deaton, C. (2012). European Guidelines on cardiovascular disease prevention in clinical practice (version 2012). International Journal of Behavioral Medicine, 19(4), 403-488. doi: doi:10.1093/eurheartj/ehs092.

Prinz, U., Nutzinger, D. O., Schulz, H., Petermann, F., Braukhaus, C., \& Andreas, S. (2013). Comparative psychometric analyses of the SCL90-R and its short versions in patients with affective disorders. BMC Psychiatry, 13, 104. doi; 10.1186/1471-244X-13-104.

Prunas, A., Sarno, I., Preti, E., Madeddu, F., \& Perugini, M. (2012). Psychometric properties of the Italian version of the SCL-90-R: a study on a large community sample. European Psychiatry, 27(8), 591-597. doi: 10.1016/j.eurpsy.2010.12.006.

Rafanelli, C., Gostoli, S., Tully, PJ e Roncuzzi, R. (2016). Hostilidade e o curso clínico de pacientes ambulatoriais com insuficiência cardíaca congestiva. Psicologia e Saúde, 31 (2), 228-238. doi: 10.1080/08870446.2015.1095299.
Sereda, Y., \& Dembitskyi, S. (2016). Validity assessment of the symptom checklist SCL-90-R and shortened versions for the general population in Ukraine. BMC Psiquiatry, 16 (1), 1-11. doi: 10.1186/ s12888-016-1014-3.

Spielberger, C. D. \& Biaggio, A. (1992). Manual do STAXI. São Paulo: Vetor.

Siegman, A. W., \& Smith, T. W. (Eds.). (2013). Anger, hostility, and the heart. Psychology Press.

Smith, T. W. (1992). Hostility and health: current status of a psychosomatic hyphotesis. Health Psychology, 11 (3), 139-150. doi: 10.1037/0278-6133.11.3.139.

Stöber, J. (2001). The Social Desirability Scale-17 (SDS17): Convergent validity, discriminant validity, and relationship with age. European Journal of Psychological Assessment, 17, 222-232. Recovered from https://kar.kent.ac.uk/4466/.

Stoney, C. M. (2013). Anger and hostility: potential mediators of the gender difference ln coronary heart disease1. Anger, hostility, and the heart. In: Siegman, A. W. \& Smith, T. Anger, Hostility, and the Heart. Lawrence Erlbawn: EUA.

Tabachnick, B. G., \& Fidell, L. S. (2013). Using multivariate statistics ( $6^{\text {th }}$ ed.). Boston, MA: Allyn and Bacon.

Tan, H., Lan, X. M., Yu, N. L., \& Yang, X. C. (2015). Reliability and validity assessment of the revised Symptom Checklist 90 for alopecia areata patients in China. The Journal of Dermatology, 42(10), 975980. doi: 10.1111/1346-8138.12976.

Wongpakaran, T., Wongpakaran, N., \& Ruktrakul, R. (2011). Reliability and validity of the multidimensional scale of perceived social support (MSPSS): thai version. Clinical Practice and Epidemiology in Mental Health: CP \& EMH, 7, 161-166. doi: 10.2174/174501790110701016.1.

Recebido em: 31/05/2018

Reformulado em: 16/07/2018; 30/08/2018 Aprovado em: 11/09/2018 
Sobre os autores:

Jaqueline Gomes Cavalcanti is a Professor at Instituto de Educação Superior da Paraíba (IESP). Master's degree in Social Psychology from Universidade Federal da Paraíba.

ORCID: http://orcid.org/0000-0002-3068-404X.

Email: gomes.jaqueline@gmail.com

Giovanna Barroca de Moura holds a Master's degree in Cooperación al Desarrollo by Universidade de Valência, with revalidation in Social Sciences at Universidade Federal do Rio Grande do Norte. She is currently a professor of Education at Universidade Estadual Vale do Acaraú.

ORCID: https://orcid.org/0000-0001-7970-4323

Email: giovannabarroca@gmail.com

Carlos Eduardo Pimentel is a Professor at the Undergraduate and Graduate Courses in Social Psychology at Universidade Federal da Paraíba. PhD in Social-Organizational and Work Psychology from Universidade de Brasília.

ORCID: https://orcid.org/0000-0003-3894-5790

Email: carlosepimentel@bol.com.br

Contato com os autores:

Av. Aragão e Melo, N. 861, Torre

João Pessoa-PB, Brazil

CEP: 58040-102 